\title{
TECHNOLOGICAL CHARACTERIZATION OF IRON ORE TAILING FROM MINERAÇÃO CONGONHAS BENEFICIATION PLANT, BRAZIL: AN IDENTIFICATION OF OPTIMUM PROCESS ROUTE
}

\author{
Aline da Luz Pascoal ' \\ Ana Paula Aparecida de Almeida Paulo ' \\ Filipe Mattos Gonçalves ' \\ Júnia Soares Alexandrino ' \\ Hygor Aristides Victor Rossoni ${ }^{2}$
}

\begin{abstract}
Technological characterization was used to define an iron ore processing route for the fraction $(-8.00+3.00 \mathrm{~mm})$ with $55.00 \%$ of $\mathrm{Fe}$ content and $17.20 \%$ of $\mathrm{SiO}_{2}$. Even having a considerable content of iron, this fraction was stored in waste piles since there was no previously interest for this fraction processing in the iron ore treatment facility of Mineração Congonhas in Catas Altas, Brazil. The characterization comprised mineralogical, chemical, granulometric and density analyzes. For the identification of the optimum process route two concentration methods were used, both in a bench scale and using a rougher stage: Route I consisted of a jigging and Route 2 used magnetic separation. The optimum concentration was encountered using the magnetic separation circuit, where the mass and metallurgical recovery were, respectively, $86.60 \%$ and 95.96 , with a concentrate of $60.94 \% \mathrm{Fe}$ and $10.91 \% \mathrm{SiO}_{2}$ content, which can then be further processed in a cleaner stage to meet the company's requirements.
\end{abstract}

Keywords: Characterization; Iron ore; Process route; Tailings.

\section{CARACTERIZAÇÃO TECNOLÓGICA DO REJEITO DE MINÉRIO DE FERRO DA PLANTA DE BENEFICIAMENTO DA MINERAÇÃO CONGONHAS, BRASIL: UMA IDENTIFICAÇÃO DA MELHOR ROTA DE PROCESSO}

\section{Resumo}

A caracterização tecnológica foi utilizada para definir uma rota de processamento do minério de ferro na fração $(-8,00+3,00 \mathrm{~mm})$, sendo esta estocada em pilhas de rejeito, mesmo possuindo teor de $\mathrm{Fe}$ de $55,00 \%$ e $\mathrm{SiO}_{2}$ de 17,20\%, pois outrora não havia interesse para o processamento desta fração na instalação de tratamento de minério de ferro da Mineração Congonhas em Catas Altas, Brasil. A caracterização compreendeu as análises mineralógica, química, granulométrica e de densidade. Para a identificação da melhor rota de processo foram utilizados dois métodos de concentração, ambos em escala de bancada e utilizando um estágio rougher: a rota I consistiu em uma jigagem e a rota 2 utilizou a separação magnética. A concentração ótima foi encontrada utilizando-se o circuito de separação magnética, que obteve, respectivamente, recuperação mássica e metalúrgica de $86,60 \%$ e $95,96 \%$, e concentrado de $60,94 \% \mathrm{Fe}$ e $10,91 \% \mathrm{SiO}_{2}$, que podem ser posteriormente processados em um estágio cleaner para atender aos requisitos da empresa. Palavras-chave: Caracterização; Minério de ferro; Rota de processo; Rejeito.

\section{INTRODUCTION}

The iron mining industry is an extremely important part of Brazil's mineral economy; Brazil has one of the largest mineral deposits in the world, is an important producer and exporter of high quality ores and is among the five largest producers globally [I]. However, the continual (and now increasing) demand for minerals has led to a reduction in the volume of existing mineral reserves. Concomitantly, as high-grade iron ores have been exhaustively mined, it has

'Departamento de Recursos Naturais, Ciências e Tecnologias Ambientais, Universidade do Estado de Minas Gerais - UEMG, Unidade João Monlevade, João Monlevade, Minas Gerais, Brasil. E-mail: filipemattosg@hotmail.com

${ }^{2}$ Departamento de Ciências Exatas e Tecnológicas, Universidade Federal de Viçosa - UFV, Florestal, MG, Brasil

2176-1523 (C) 2019 Associação Brasileira de Metalurgia, Materiais e Mineração. Publicado pela ABM. Este é um artigo de acesso aberto distribuído sob os termos da licença Creative Commons CC BY-NC-ND (Attribution-NonCommercial-NoDerivs) - https:// creativecommons.org/licenses/by-nc-nd/4.0\%. 
become necessary to use low-grade iron ores, fines, and slimes to meet growing demands [2]. Therefore, the mining sector recognizes the need for improvement and seeks to determine new techniques that will improve the recovery and productivity of mineral deposits [3] with the ultimate aim of recovering a greater proportion of the metallic content and using previously discarded granulometric fractions [4].

In this study, characterization of iron ore tailings is undertaken to improve the use of mineral resources. This is a fundamental step in providing the necessary mineralogical and textural content to subsequently determine the correct processing route, and to identify precision inefficiencies and losses relating to existing processes, thereby enabling optimization of the overall treatment facility performance [5]. Moreover, it is extremely important from economic and environmental perspectives to improve processes and concentration circuits, and to take advantage of directly using residues in the metallurgical industry to guarantee an increase in mine life [6].

The iron ore mine of Mineração Congonhas (Micon) is located in the city of Catas Altas, Brazil. It also has an ore treatment plant that comprises comminution stages, granulometric classification, and concentration using magnetic separation with rougher, cleaner, and recleaner stages. At that time, the fraction $(-8.00+3.00 \mathrm{~mm})$ with a Fe content of $55.00 \%$ and $\mathrm{SiO}_{2}$ of $17.20 \%$ was considered as waste by the company, due to the large volume of the iron ore deposit which contained other richer areas. Therefore, there was a lack of interest in processing this fraction granulometry that was disposed in tailings. The existing circuit at Micon's ore treatment plant does not recover this fraction to produce the $-2.00 \mathrm{~mm}$ concentrate that meets specifications of the company's consumer market for an Fe content higher than $63.00 \%$ and an $\mathrm{SiO} 2$ content lower than $8.00 \%$.

In this respect, this work represents a technical feasibility study of fraction reuse and presents technological characterization of iron ore tailings with the aim of defining the optimum processing route using either jigging or magnetic separation.

\section{MATERIALS AND METHODS}

Iron ore tailing was collected from the yard of the ore treatment facility at Mineração Congonhas and was characterized with respect to its chemical and mineralogical composition, granulometric distribution, and density. Chemical analysis was conducted using plasma spectometry which enabled quantification of $\mathrm{Fe}, \mathrm{SiO} 2, \mathrm{Al} 2 \mathrm{O} 3, \mathrm{P}, \mathrm{Mn}$ contents and by loss on ignition (LOI). The true density of the sample was determined using the pycnometry method. Mineralogical analysis was conducted using optical reflected light microscopy (with Leica petrographic microscopes models DMLP, DM2500P, and DM6000M). The granulometric distribution was obtained by dry screening using a mechanical bench sieve and by wet screening using a mechanical suspended sieve. Dry screening was conducted for the fraction $(-8.00+3.00 \mathrm{~mm})$ with the following sieve openings $(\mathrm{mm}): 9.50 / 8.00 / 6.30 / 5.60 / 4$. 00/3.50/2.40/I.40/0.85/0.60/0.50/0.2I 2 .

After results of mineralogical and chemical analyzes had been obtained, it was necessary to reduce the iron ore tailing to a fraction of $-2.00 \mathrm{~mm}$ to conduct concentration tests. For a fraction of $-2.00 \mathrm{~mm}$, dry and wet screening was conducted using the following sieve openings $(\mathrm{mm})$ : 2.00/1.00/0.50/0.25/0.15/0.106/0.075/0.063/0.045/0.037.

Comminution of iron ore tailings in the fraction $(-8.00+3.00 \mathrm{~mm})$ to $-2.00 \mathrm{~mm}$ was necessary to release $\mathrm{SiO} 2$ present in iron ore samples. From this, two concentration methods were conducted on a bench scale, both using a rougher stage: one (Route I) involved jigging, and another (Route 2) using magnetic separation. The jigging test used a Denver jig (model H46A DEC 0) with a frequency of $30 \mathrm{~Hz}$, spheres with diameters of $6.00 \mathrm{~mm}$, screen aperture of $1.68 \mathrm{~mm}$, and washing water with a flow rate of $19.0 \mathrm{ml} / \mathrm{s}$. The magnetic separation test was performed in a magnetic separator type L4 (model WHINS 3X4L Inbrás) with a magnetic field of 7,000 Gauss.

\section{RESULTS AND DISCUSSION}

The results of chemical analysis were in accordance with those obtained by mineralogical analysis, as presented in Table I.

Silica $\left(\mathrm{SiO}_{2}\right)$ is the main contaminant of iron ores and mineralogical analysis showed that this iron ore had a $\mathrm{SiO}_{2}$ content of $15.00 \%$ (Table I). As the aim was to obtain a silica concentration of less than $8.00 \%$ with gravitational concentrations for the iron ore fraction of $-8.00+3.00 \mathrm{~mm}$, comminution was then required to release the $\mathrm{SiO}_{2}$ present in the samples and to reduce the particle size to $-2.00 \mathrm{~mm}$. As cited by Chaves [7] and Wills and Napier-Munn [8], most mineral species are associated and it is thus necessary to separate them from each other to enable optimum industrial use.

The granulometric distributions of fractions $(-8.00+3.00 \mathrm{~mm})$ and $-2.00 \mathrm{~mm}$ are presented in Figure I. The D80 of the fraction $(-8.00+3.00 \mathrm{~mm})$ was $4.70 \mathrm{~mm}$, and it was $1.00 \mathrm{~mm}$ for the fraction $-2.00 \mathrm{~mm}$.

Table I. Comparison between results obtained by Mineralogical and Chemical Analysis of iron ore tailings in the fraction $(-8.00+3.00 \mathrm{~mm})$

\begin{tabular}{|c|c|c|c|c|c|c|c|c|c|}
\hline \multicolumn{5}{|c|}{ Mineralogical Analysis (\%) } & \multicolumn{5}{|c|}{ Chemical Analysis (\%) } \\
\hline $\mathbf{F e}$ & $\mathrm{SiO}_{2}$ & $\mathrm{Al}_{2} \mathrm{O}_{3}$ & $M n$ & LOI & $\mathbf{F e}$ & $\mathrm{SiO}_{2}$ & $\mathrm{Al}_{2} \mathrm{O}_{3}$ & $M n$ & LOI \\
\hline 58.50 & 15.00 & 0.73 & 0.01 & 0.69 & 55.00 & 17.20 & 0.84 & 0.07 & 0.58 \\
\hline
\end{tabular}


The true density of the iron ore sample was determined as $4.47 \mathrm{~g} / \mathrm{cm}^{3}$ using the pycnometry method.

Figure 2 shows the mineralogy of the iron ore tailing in the fraction $(-8.00+3.00 \mathrm{~mm})$. The iron minerals identified were hematite, magnetite, and goethite; worthless minerals identified were quartz, gypsite, and kaolinite. In relation to the fraction under study, the percentage of mixed quartz already showed the need to use comminution to release silica $(10.53 \%)$ and obtain a concentrate with a silica content lower than $8.00 \%$.

Figure 3 presents a sequence of photomicrographs of the fraction under study, showing the concentration of porous particles that are sometimes filled with kaolinite, and quartz that is less liberated as it is associated with hematite.
The main particles in the jigging concentrate (particles with greater densities) were: goethites (those with low porosity); martitic hematite (with fully filled goethite pores); polycrystalline hematite particles (with low porosity and less than $10 \%$ by volume); particles formed by the association of iron/quartz minerals (where quartz has a similar proportion to iron minerals and a porosity of less than 10\%). For the magnetic concentration of iron ores, it is essential that mineral particles are susceptible to magnetic fields with a well-defined intensity. Figure $4 \mathrm{a}$ and $\mathrm{b}$ compare the performance results between jigging (Route I) and magnetic separation (Route 2) tests for the concentrate and the tailing in relation to mass recovery ( $R$. Mass), metallurgical recovery ( $R$. Metal), and the iron $(\mathrm{Fe})$ and silica $\left(\mathrm{SiO}_{2}\right)$ contents.

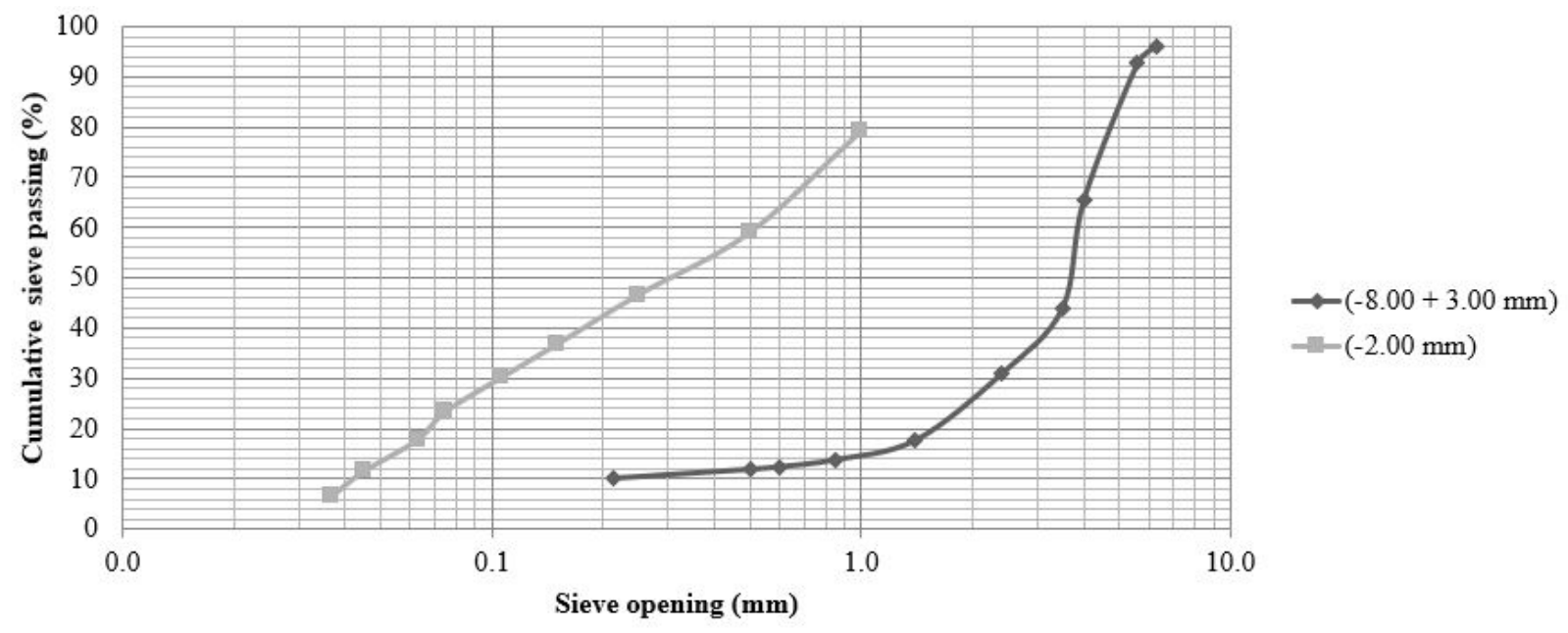

Figure I. Particle size distribution of fraction $(-8.00+3.00 \mathrm{~mm})$ and fraction $-2.00 \mathrm{~mm}$.

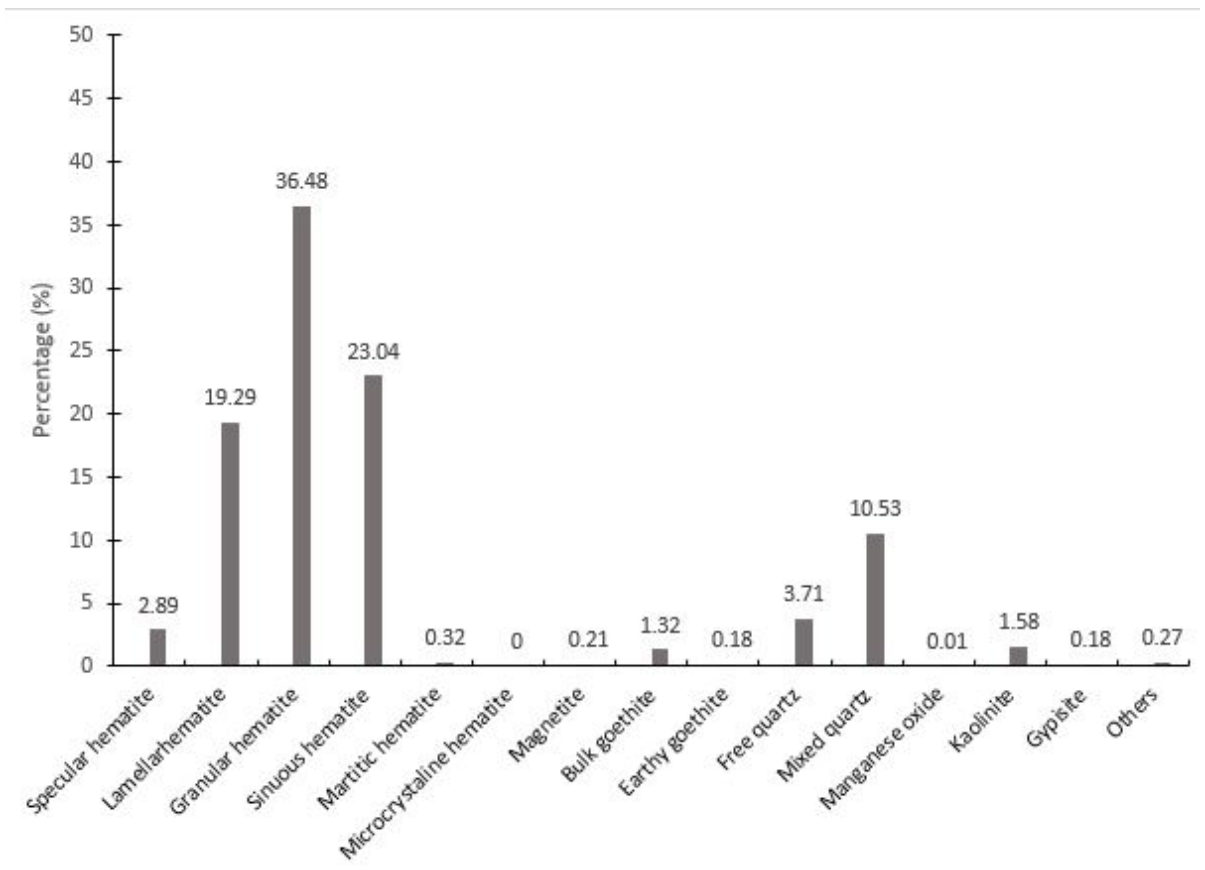

Figure 2. Mineralogy of iron ore tailing fraction $(-8.00+3.00 \mathrm{~mm})$. 


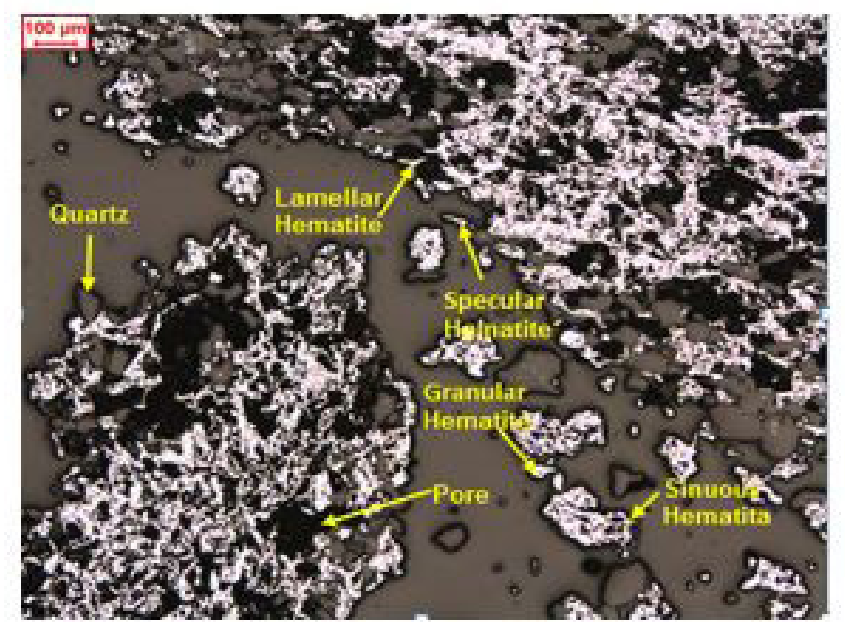

(a)

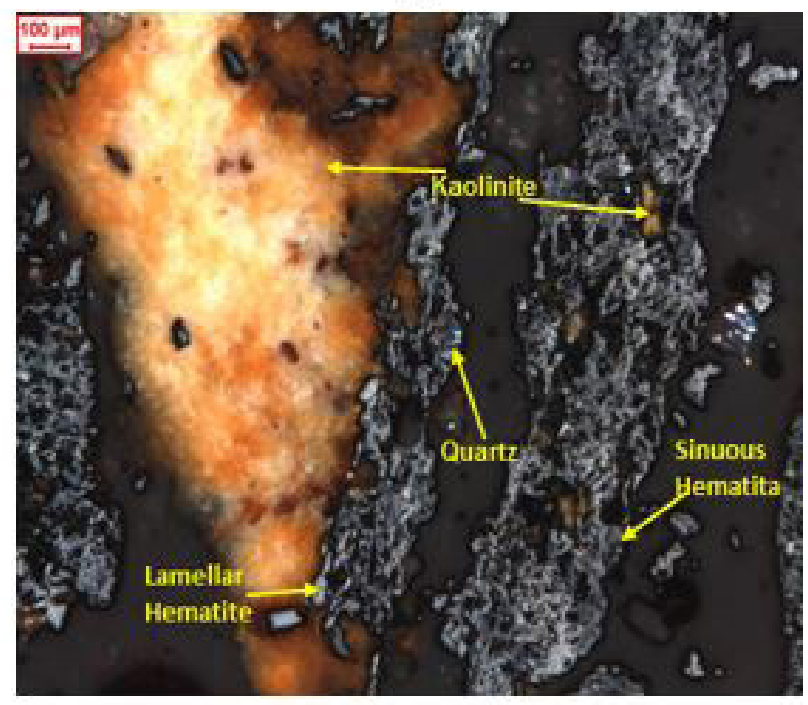

(c)

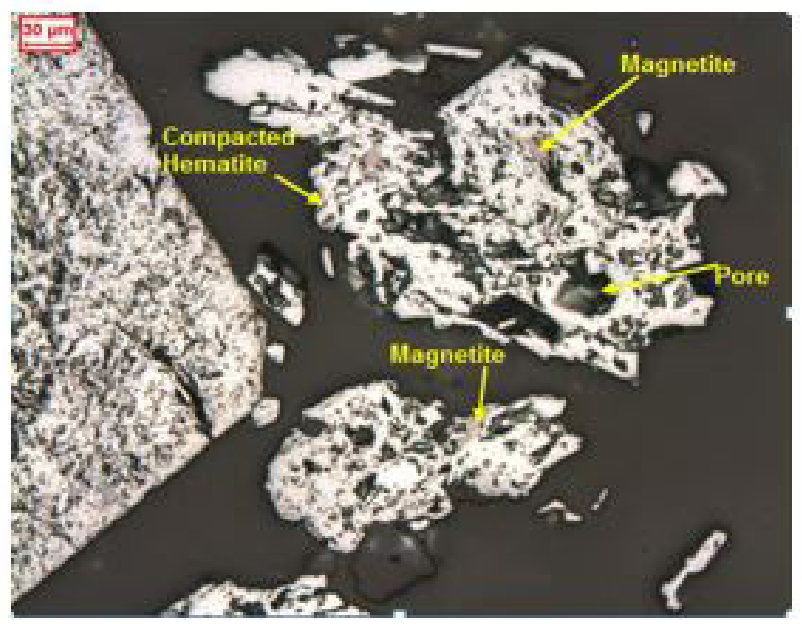

(b)

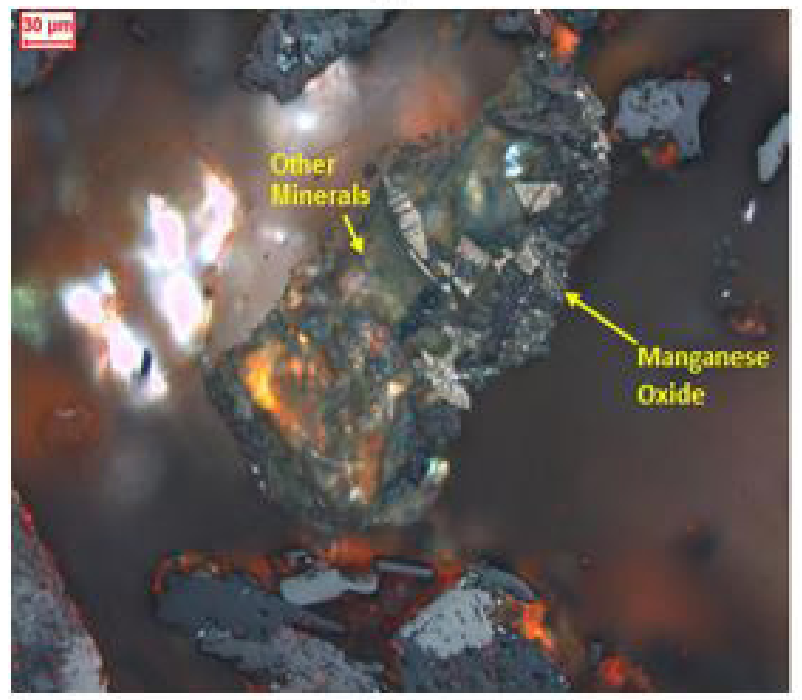

(d)

Figure 3. Main mineralogical features of fraction $(-8.00+3.00 \mathrm{~mm})$ : (a), (b), (c), (d).

As demonstrated in Figure 4a, a concentrate with an $\mathrm{SiO} 2$ content of $8.53 \%$ and $\mathrm{Fe} 62.63 \%$ was obtained using Route I, while the concentrate had an $\mathrm{SiO} 2$ content of $10,91 \%$ and Fe content of $60.94 \%$ using Route 2 . These contents are close to the product specifications of the company (Fe contents $>63.00 \%, \mathrm{SiO} 2<8.00 \%$ with a mass recovery of $>50.00 \%$ ).

In relation to recoveries using the routes employed in this study, Route I did not provide satisfactory mass recovery results $(46.91 \%)$, and it was not possible to reprocess the concentrate in a cleaner stage to reduce the silica content. However, the use of Route 2 provided a significant mass recovery $(86.60 \%)$, and this concentrate can be then processed using a cleaner stage. Route 2 also showed a considerable metallurgical recovery of $95.95 \%$.
Thus, it was observed that the hydrodynamic drag of fines generated a metallic loss for the tailings, which was also seen in the tests conducted by Barcelos [9]. Figure 4b shows that the waste from Route I had a high Fe content (48.27\%). This increased amount (compared to Route 2) is related to the hydrodynamic drag of fines and of ultrafine particles, which are characterized by lower masses and lower metallurgical recoveries.

Studies conducted by Voigt and Twala [ 10$]$ confirmed that separation of finer particle sizes using the differential sedimentation mechanism is not very effective.

However, the best results were obtained in the concentration with respect to Route 2 , which generated a good quality concentrate and good mass and metallurgical recovery values. 


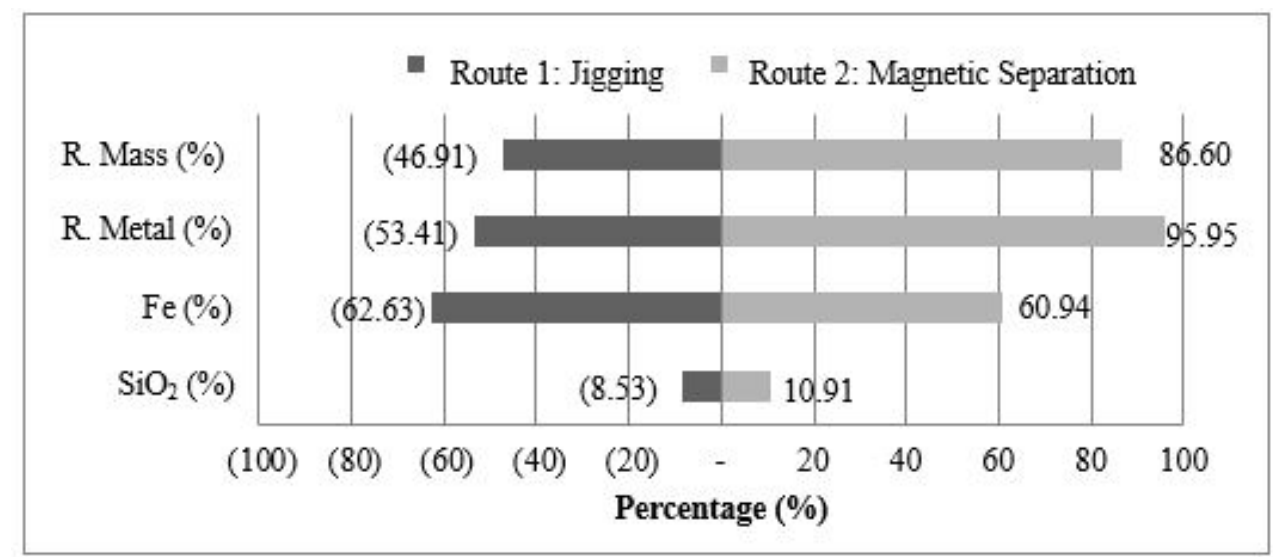

(a)

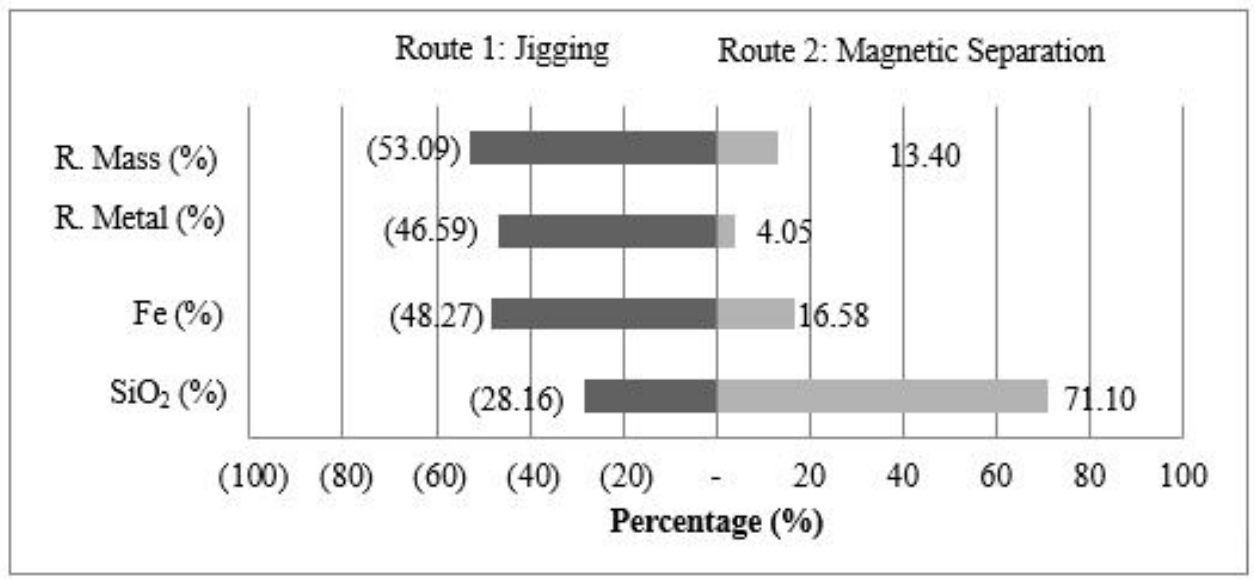

(b)

Figure 4. Comparative performances of Routes I and 2: (a) concentrate and (b) tailing.

\section{CONCLUSIONS}

Mineralogical characterization showed that nearly all iron is associated with hematite and quartz, which are responsible for nearly all the $\mathrm{SiO}_{2}$ present in the iron ore tailing fraction $(-8.00+3.00 \mathrm{~mm})$. As it was necessary to reduce the fraction to $-2 \mathrm{~mm}$, in the final adjustment of the operational cycle it was clearly evident that selectivity of the gravitational concentration was extremely affected.

The results obtained in this study show it is possible to obtain an iron ore tailing concentration in the fraction $(-8.00+3.00 \mathrm{~mm})$ using the magnetic concentration method (Route 2). The mass and metallurgical recoveries using this method were $86.60 \%$ and $95.96 \%$, respectively, with a concentrate of $60.94 \% \mathrm{Fe}$ and $10.91 \% \mathrm{SiO}_{2}$. Therefore, this route has considerable potential for use in reprocessing iron ore tailing, if subsequent methods are also employed to meet the company's product specifications. Using tailing reprocessing will increase both productivity and the life of the mine, in addition to providing economic and environmental gains, as there would be no need for beneficiation plant change and the company would recover a material that was previously stocked as waste.

\section{Acknowledgements}

The authors would like to thank the Mineração Congonhas for the support in carrying out this work.

\section{REFERENCES}

I United States Geological Survey. Mineral commodity summaries 2017. Reston: USGS; 2017.

2 Kumar R, Mandre NR. Recovery of iron from iron ore slimes by selective flocculation. Journal of the Southern African Institute of Mining and Metallurgy. 2017; I I7(4):397-400. 
Pascoal et al.

3 Rocha L, Peres AEC. Aproveitamento econômico das lamas de ferro. International Engineering Journal. 2009;62(3):29I-295.

4 Dworzanowski M. Maximizing the recovery of fine iron ore using magnetic separation. Journal of the Southern African Institute of Mining and Metallurgy. 2012;1 I2(3): 197-202.

5 Nuemann R, Schneider CL, Alcover A No. Tratamento de minérios: caracterização mineralógica de minérios - Parte II. 5. ed. Rio de Janeiro: CETEM/MCT; 2010.

6 Reis EL, Lima RMF. Concentração de finos provenientes da planta de beneficiamento do minério de manganês da Mineração Morro da Mina/RDM por mesa oscilatória. International Engineering Journal. 2005;58(3):225-229.

7 Chaves AP. Teoria e prática do tratamento de minérios. 2. ed. São Paulo: Signus; 2010.

8 Wills BA, Napier-Munn T. Wills' mineral processing technology: an introduction to the practical aspects of ore treatment and mineral. 7th ed. Oxford: Elsevier Science \& Technology Books; 2006.

9 Barcelos HO. Jigagem de minérios itabiríticos [tese]. Ouro Preto: Universidade Federal de Ouro Preto; 2010.

10 Voigt AE, Twala C. Novel size and shape measurements applied to jig plant performance analysis. Journal of the Southern African Institute of Mining and Metallurgy. 20 I2; I I2(3): I7 I-I 77.

Received: 27 Out. 2018

Accepted: 18 June. 2019 